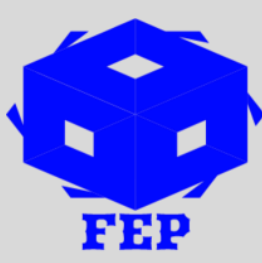

\title{
IMPLICATIONS OF POOR WASTE DISPOSAL MANAGEMENT PRACTICES ON SENIOR HIGH SCHOOLS WITHIN THE WA MUNICIPALITY OF GHANA
}

\author{
Justice Agyei Ampofo, ${ }^{1,2}$ \\ ${ }^{1}$ University for Development Studies, Tamale (Ghana) \\ ${ }^{2}$ University of Education, Winneba (Ghana)
}

*Corresponding Author: Justice Agyei Ampofo

Corresponding Author Email: papajusty@gmail.com

Article Received: 29-07-20

Accepted: $19-08-20$

Published: 05-09-20

Licensing Details: Author retains the right of this article. The article is distributed under the terms of the Creative Commons Attribution-NonCommercial 4.0 License (http://www.creativecommons.org/licences/by-nc/4.0/) which permits non-commercial use, reproduction and distribution of the work without further permission provided the original work is attributed as specified on the Journal open access page.

\section{ABSTRACT}

The management of waste has become one of the key environmental concerns of the past decades with hundreds of scientific papers published on the topic every year. However, there seems to be paucity of studies on the implications of poor waste disposal management practices on schools in general in Ghana and Wa Municipality in particular. The purpose of this study was to investigate the implications of poor waste disposal management practices on Senior High Schools in Wa Municipality. The study adopted a mixed method explanatory sequential approach with both qualitative and quantitative data collection and analysis. The tools used to capture the required data includes, questionnaires, interview schedules and observation. The study respondents were students, teachers and school management of selected Senior High Schools within the Wa Municipality of the Upper West Region of Ghana. The study respondents were one hundred and twenty two (122) respondents comprising 45 students, 45 teachers, 30 school management officials, 1 education officer and 1 waste management officer. The study revealed that, the commonest type of waste generated within the Senior High Schools in the Municipality were food waste, rubbish, papers, plastic materials. Key findings of the research shows that waste was not separated into plastics, papers, organic waste and was haphazardly disposed due to lack of dustbins. Again, the study found out that uncollected waste in Senior High Schools causes poor sanitation. It also emerged from the study that high rate of population growth in Senior High Schools within the Wa Municipality have resulted in the generation of an enormous volume of solid waste, which poses a serious threat to environmental quality and human health and this causes 
disease outbreaks; cases of cholera as well as other diarrhea diseases in Senior High Schools within the Wa Municipality. The study recommends that the Wa Municipal Assembly and ZoomLion Company should supply dustbins to Senior High Schools within the Wa Municipality. Finally, the study recommends adequate resourcing of waste disposal management for Senior High Schools within the Wa Municipality. The waste management institutions should be adequately resourced to ensure efficient and effective waste disposal management in Senior High Schools within the Wa Municipality. The Wa Municipal Assembly should liaise with other corporate bodies like the United Nations Development Program (UNDP) to pull financial resources to support the institutions in charge of managing waste especially the ZoomLion Ghana Ltd. With the support, adequate dustbin and core waste disposal management equipment such as compaction trucks roll on/roll off trucks, skip loaders would be purchased to ensure effective waste collection and disposal.

Keywords: Implications, Poor Waste Disposal Management Practices, Senior High Schools Wa Municipality.

\section{INTRODUCTION}

Since the turn of the new millennium, there has been a proliferation of discourse on poor waste disposal management practices emanating from virtually all visages of academic and policy circles (Gebril, 2010; Adewusi, 2016). Conceivably, the most surprising feature of the expansive literature is not the enormous size, or the diversity of disciplinary perspectives from which analysts have approached the subject, but rather the perfunctory attention given to the Ghanaian situation (Parker, 2003; Agyei et al, 2009; Yurttas; 2010; PAR, 2011; Owusu, 2014; ISSER, 2017).

The management of waste in Senior High Schools attracts increasing attention all over the world as people are becoming conscious of a variety of environmental problems such as global warming, air, water and land pollution (UNEPA, 2016). Waste generated as part of daily human activities not only damages natural resources, but the potential negative impacts on the environment or human health cannot be excluded (Post, 2012). There are emerging environmental concerns in Wa Municipality as a result of the improper disposal of solid and liquid hazardous waste within the township (Simon, 2014; Zahari, 2017).

Consequently, waste (solid and liquid) is not only increasing in composition but also changing in quantity (Owusu-Sekyere, 2015). UN Habitat (2008) indicated that present-day municipal solid waste (MSW) generates waste amounting to 277 million tons annually. Low and middle-income countries generate $12.2 \%$ and $57.1 \%$ of that waste respectively, whilst high income countries generate $30.7 \%$. This figure is expected to increase to 677 million tons by 2025 . The percentage of waste generated in high-income countries will be $12.7 \%$, whilst it will be $16.4 \%$ and $70.9 \%$ in middle and low-income countries, respectively (UN Habitat, 2008).

Ghanaians including students, teachers and school management have a very poor attitude towards environmental sanitation in general and waste disposal in particular. People are fond of discarding waste indiscriminately. For example, the Daily Guide and the Daily Graphic on August 22 $2^{\text {nd }}, 2007$ and May 19 th 2008; respectively all commented on the poor waste management practices in schools (Kumah, 2007; Agyei, 2009; Gamble, 2012; Post, 2012).The changing economic trends, urbanization and rapid increase in student's population 
complicate solid waste management in developing countries.

In an attempt to rectify the numerous challenges associated with poor waste management practices within Senior High Schools, most developing countries have opted for the construction of landfills. The rationale is that landfills are the most feasible option of waste disposal due to its cost effectiveness and low negative environmental impact (Owusu, 2014:2015).

Stakeholders of the educational sector in Senior High Schools in Ghana are putting in much efforts to manage waste but despite the attempts such as Public Private Partnership involvement, unfortunately, Ghana had still been tagged as one of the dirtiest countries in the world due to its poor waste management as a factor (Wilson, 2007; Post, 2012). Though, a lot have been studied about the health, financial, social, economic and environmental implication emanating from poor waste management practices in schools (Boateng, 2006), there is lack of information on the implications of poor waste disposal management practices on Senior High Schools in the Wa Municipality of the Upper West Region of Ghana and such remains a knowledge gap and a problem that needs an attention.

\section{REVIEW OF RELATED LITERATURE}

\section{Definition of Concepts}

\section{Waste}

As noted by Martin (2011), the term 'waste' is frequently left as an undefined primitive in spite of its critical importance" and "frequently, a list of types of waste is substituted for the underlying definition." Boadi (2004), also describes waste as "unwanted or unusable materials that emanate from numerous sources from industry and agriculture as well as businesses and households and can be liquid, solid or gaseous in nature and hazardous or non-hazardous depending on its location and concentration." Drawing from the views expressed above, the definition of waste as used in this study is any substance (liquid, solid, gaseous or even radioactive) that is discarded into school environment because it is unwanted, which causes significant nuisance or adverse impact on social, economic, financial, environmental and academic.

\section{Solid Waste}

Solid waste can be defined as non-liquid and non-gaseous products of human activities, regarded as being useless. It could take the form of refuse, garbage and sludge, (Parker, 2003). To add to this, solid waste is the unwanted or useless solid materials generated from schools in a given area. Waste is burnt in pits, dumped in random locations, or disposed of in uncontrolled dumps without and further management. According to Post (2012), solid waste is any material that is solid and discarded as unwanted dumped in refuse disposal site. Solid wastes are materials with less liquid content, characterized by a reactive and unstable nature when exposed to heat, some of these include acids or bases that can corrode metal containers (Misra, 2005; Akpen, 2005; GSS, 2012; Owusu, 2015).

\section{The Nature of the Poor Waste Disposal Management Practices in Senior High Schools in Developing Countries}

While data is generally lacking in waste management practices in Senior High Schools in most developing countries including Ghana, available studies on the topic suggest that, waste management in generally characterized by inefficient collection methods, insufficient 
coverage of the collection systems and improper disposal of waste (Mensah, 2005; Gyebi, 2010; Martin, 2011). The environment of many Senior High Schools are therefore, characterized by waste accumulations and poor environmental sanitation (UN Habitat, 2012). In 2012, the United Nations Centre for Human Settlement (UN-Habitat) raised concerns about the solid waste situation in cities are poor countries the following word. The need for the collection and disposal of solid waste is far from adequately recognized (UN Habitat, 2012).

In many Third World cities, writers suggest that large proportions (between 30 and 50 percent) of the solid waste generated by people are never collected for disposal, end up rotting on the streets, in drains and in streams. (Gyebi, 2010), for instance have reported the extensive lack of solid waste collection in schools across the developing world. Martin (2011) postulated that there is lack of provision for proper waste management in Senior High Schools and the resulting effect is poor environmental conditions.

The poor waste disposal situations in Senior High Schools in developing countries can have enormous implications on health, economic, finance and the environment. The decomposing piles of wastes, especially in Senior High Schools in Ghana have the potential to attract and harbor vermin and rodents which spread diseases (Tsiboe, 2004; Kumah, 2007; Momoh et al, 2010; Mensah, 2012; Owusu, 2015). The accumulated wastes also attract foraging animals like dogs and goats which scatter infected waste materials, spreading diseases and causing a nuisance (Bello, 2008:2009).

\section{Implications of Poor Waste Disposal Management Practices}

Poor waste disposal management activities in Senior High Schools can bring about the following:

1. Increase in disease transmission or otherwise threaten students, teachers, school management and people working in the school health. Rotting organic materials pose great public health risks, including, as mentioned above, serving as breeding grounds for disease vectors. Waste handlers and waste pickers are especially vulnerable and may also become vectors, contracting and transmitting diseases when human or animal excreta or medical wastes are in the waste stream.

2. Contaminate grounds due to the poor waste disposal can bleed toxic materials and pathogenic organisms into an open refuse dump, and other ailments are also high causing mixing with leachate, and threatening the health and water supply of the surrounding school area. If the waste dump site is unlined, this runoff can contaminate ground or surface water, depending on the drainage system and the composition of the underlying soils.

3. Poor waste disposal creates greenhouse gas emissions and other air pollutants. When organic wastes are disposed off in schools' dumps sites, they undergo anaerobic degradation and become significant sources of methane, a gas with 21 times the effect of carbon dioxide in trapping heat in the atmosphere. Garbage is often burned in school surroundings to reduce volume and uncover metals. Burning creates thick smoke that contains carbon monoxide, soot and nitrogen oxides, all of which are hazardous to human health.

4. Injure people and property. In schools where shantytowns or slums exist near open dumps or near badly designed or operated dump sites, landslides or fires can 
destroy schools and injure or kill students. The accumulation of waste in school surroundings may present physical hazards, clog drains and cause localized flooding.

5. The unpleasant odour and unattractive appearance of piles of uncollected solid waste in schools can discourage people from schooling (Seo, 2006).

\section{METHODOLOGY}

\section{Research Method}

A concurrent mixed method approach was adopted for this study, involving both qualitative and quantitative data collection methods. Quantitative data was collected using questionnaires. These tools captured the required data as follows; factors contributing to poor waste disposal management practices in Senior High Schools within the Wa Municipality, impacts of poor waste disposal management practices on Senior High Schools within the Wa Municipality and measure to improve waste management practices in Senior High Schools within the Wa Municipality. Qualitative data was captured using Key Informants Interview (KII) guides with key stakeholders at the Municipal Department of Waste Management Office, Environmental Protection Agency and Director of Education at Wa Municipality.

Mixed method approaches was used for this study because it can answer a broader and more complete range of research questions because the researcher is not confined to a single method or approach (Creswell, 2013; Ampofo, 2019). Mixed-methods can also provide stronger evidence for a study's conclusions through convergence and corroboration of findings (Creswell, 2013). In a concurrent approach, two or more data collection instruments are administered within the same time frame. The researcher collected both forms of data (questionnaire and interview) at the same time during the study, and then integrated these data into the interpretation of the overall results (Ampofo, Amoah \& Peprah, 2020).

\section{Research Design}

In this study the researcher used a mixed method explanatory sequential design, with both qualitative and quantitative data collection and analysis, but the quantitative data is more than the qualitative. Explanatory sequential design involves the procedure of first collecting quantitative data and then collecting qualitative data to help explain or elaborate the quantitative results (Creswell, 2013). Explanatory sequential design also uses instruments such as questionnaires and interviews to gather information from groups of subjects (Creswell, 2013, Ampofo, 2019, Ampofo, Nassè, Amoah \& Peprah, 2020).

\section{The Study Area}

The study was conducted in three selected public Senior High Schools namely Wa Senior High Technical School, Wa Senior High School and Wa Technical Institute all within the Wa Municipality in the Upper West Region of Ghana. A preliminary survey by the researcher in the above three selected public Senior High Schools, shows that waste generation is very high in these schools as such this has been an issue of concern among the various stakeholders of the educational sector in the Municipality. The researcher's work experience as a teacher has helped me gain access to the information needed for the successful completion of this study. The schools are within my locality, (Wa Municipal) hence, reducing the cost as well as risk involved in travelling. This made the data collection process easy and convenient. 


\section{Population}

The target population consisted of all the students, teachers and school management in the selected three Senior High Schools within the Wa Municipality. The study population also included the Wa Municipal Assembly officer in charge of Waste Management, some personnel of the Environmental Protection Agency and Wa Municipal Education Director. The students, teachers and school management were the target group because; they are in the schools and as such the implications of poor waste management practices comes to them direct hence they were more likely to have knowledge about the implications of poor waste management practices. Table 1 shows students population distribution for three schools.

Table 1

Target Student Population Distribution for 2017

\begin{tabular}{|c|c|c|c|}
\hline \multirow[b]{2}{*}{ SENIOR HIGH SCHOOL } & \multicolumn{3}{|c|}{ STUDENTS POULATION } \\
\hline & FORM 2 & FORM 3 & TOTAL \\
\hline 1. Wa Senior High Technical School & 600 & 540 & 1140 \\
\hline 2. Wa Senior High School & 560 & 480 & 1040 \\
\hline 3. Wa Technical Institute & 520 & 560 & 1080 \\
\hline TOTAL & 1680 & 1580 & 3260 \\
\hline
\end{tabular}

Table 2 shows teachers population distribution for the three schools.

Table 2

Teacher Population Distribution for the three Schools in 2017

\begin{tabular}{cllll}
\hline & & \multicolumn{3}{c}{ TEACHERS POPULATION } \\
SENIOR HIGH SCHOOL & FEMALE & MALE & TOTAL \\
\hline 1. & Wa Senior High Technical School & 14 & 76 & 90 \\
2. & Wa Senior High School & 16 & 70 & 86 \\
3. & Wa Technical Institute & 20 & 75 & 95 \\
\hline & TOTAL & $\mathbf{5 0}$ & $\mathbf{2 2 1}$ & $\mathbf{2 7 1}$ \\
\hline
\end{tabular}

Source: Field Survey (2018)

Table 3 shows the distribution of school management/staff population for the three schools.

Table 3

Distribution of Population of the three Schools' Management for 2017

\begin{tabular}{cllll}
\hline & & \multicolumn{3}{l}{ SCHOOL MANAGEMENT POPULATION } \\
SENIOR HIGH SCHOOL & FEMALE & MALE & TOTAL \\
\hline 1. & Wa Senior High Technical School & 7 & 6 & 13 \\
2. Wa Senior High School & 5 & 6 & 11 \\
3. & Wa Technical Institute & 9 & 5 & 14 \\
\hline \multicolumn{6}{c}{ TOTAL } & $\mathbf{2 1}$ & $\mathbf{1 7}$ & $\mathbf{3 8}$ \\
\hline \multicolumn{2}{c}{ Source: Field Survey (2018) }
\end{tabular}

The teachers have a total population of 271, students have a population of 3260 and school management has a population of 38, 1 Municipal Education Officer and 1 Municipal Waste Management Officer. Therefore the total population of this study was 3571. This group of population was selected because they could provide useful information concerning the study. 


\section{Sample Size and Sampling Techniques}

Ampofo (2020) explains that, 'it is imperative for you to determine an aspect of population to be involved in your study.' A study may entail a large population unlike others with small population. In such situation, a portion of the entire population may be selected for study and this is what is termed as sample. In selecting sample for the study, the researcher made use of simple random sampling technique in selecting all the respondents. In all one hundred and twenty two (122) respondents were selected for the study comprising 45 students, 45 teachers and 30 school management officials. Also, 1 education officer and 1 waste management officer were also interviewed. This sample size was chosen for the researcher to be able to manage them.

\section{Instrumentation}

Questionnaire and interview guide were used for this study. A questionnaire is a research instrument consisting of series of questions for the purpose of a survey or statistical study. The structured questionnaire type was used. Ampofo (2019) explains that a structured questionnaire is a data collection instrument which contains predetermined standard questions or items meant to collect numerical data that can be subject to statistical analyses. He explains that the questions are close ended and answers outlined, which gives respondents the opportunity to respond to sample questionnaire questions.

The questionnaire was both close ended and open-ended questions with options like (Strongly Agree, Agree, Disagree, Strongly Disagree and Uncertain). It was divided into two sections which are as follows: Section A, deals with personal data and demographic information of the respondents. Section B, provides questions on the impacts of poor waste disposal management practices onSenior High Schools within the Wa Municipality. Questionnaires required less time and money compared to other methods like focus group discussions (Ampofo \& Acheampong, 2019). On the whole the respondents responded to thirty (30) questions which were Likert-scale type. However, there were few open-ended questions and interviews which allowed participants to share their views that were not captured. This was to combat the negative side of the structured questionnaire.

\section{Pretesting of the Instrument}

A pilot study was conducted in Wa Islamic Senior High School in the Wa Municipality of the Upper West Region of Ghana which has the same socio- demographic as that of Wa Senior High Technical School, Wa Senior High School and Wa Technical Institute. The pilot study was done to improve the reliability of the instrument. Changes were made to questions deemed inappropriate after the pilot study.

\section{Validity of the Instruments}

A research instrument is said to be valid when it measures what it is supposed to measure. Face validity is in relation to the misunderstanding and misinterpretation of the question. This was checked by way of employing pretesting method. Content validity on the other on other hand refers to the capacity of the instrument to prove adequate coverage of a topic. Adequate preparation of the instrument under the guidance of the supervisor, expert opinion and pretesting of the question helped established the content validity.

\section{Reliability of the Study}

Reliability has to do with an instrument consistently producing the same result every time it is used. The test retest method was used to test for the reliability of the instrument. The 
questionnaires were administered to students and teachers of Wa Northern Star Senior High School which has the same socio- demographic as that of teachers, students and management of the selected three Senior High Schools. The same questionnaires were administered to them after two weeks.

\section{Data Collection Procedure}

The researcher obtained permission from the heads of the selected Senior High Schools within the Wa Municipality to seek their approval and access to the school. The participants were told of the purpose, time, venue and how to answer the questionnaires. They were also assured of their confidentiality and anonymity. The researcher self-administered the questionnaires personally in order to clearly issues to the participants. On the whole the researcher spent two weeks for the collection of the data. All respondents responded to the questionnaire.

\section{Data Analysis Techniques}

The data gathered by the above instrument were first coded, categorized and then analyzed using SPSS (version 20). The data analyses include generating the frequencies and percentages upon which the interpretations were made. Frequency counts and percentage were applied to items in section 'A' of the questionnaire which include respondents' demographic information like gender and years of experience. The use of descriptive statistics, notably frequency and percentage were used to analyze the data that was collected from the field on the impacts of poor waste disposal management practices on Senior High Schools within the Wa Municipality. Analysis is applied to see the relationships of students, teachers and school management views as well as the relationship of these scales. The process of data analysis was done with reference to research objectives, and findings to make recommendations to education stakeholders.

\section{DISCUSSION OF FINDINGS}

\section{Demographic Analysis of Respondents}

The initial aspect of the data analysis focuses on a summary statistic of the respondents. The study captured the views of students, teachers and school management of the three selected public Senior High Schools in the Wa Municipality concerning the implications of poor waste disposal management practices on schools. The descriptive analysis therefore implemented on the three classes of respondents. Tables 4 and 5 give a report of the summary statistics of the sampled respondents.

It offers demographic information about the respondents' gender, their position, age, experience and highest level of education. Majority of the students who responded to the survey instrument were males (55.56\% representing 25 out of the total of 45 students). It is also detected that most of the sampled students (44.44\%) are between the ages of 19 23years. Meanwhile, the researcher mostly concentrated on all the students, (SHS 1, SHS 2 and SHS 3) who were equally represented (33.33\%) respectively each as all this group was assumed to possess enough information concerning the implications of poor waste disposal management practices on Senior High Schools within the Wa Municipality of the Upper West Region of Ghana. 
Table 4

\begin{tabular}{clll} 
Demographic & \multicolumn{3}{c}{ Characteristics of Sampled Stuc } \\
\cline { 2 - 4 } Gender & Details & Frequency & Percent \\
\hline \multirow{6}{*}{ Age } & 25 & 55.56 \\
& Female & 20 & 44.44 \\
& Total & $\mathbf{4 5}$ & $\mathbf{1 0 0}$ \\
& $14-18$ & 15 & 33.33 \\
& $19-23$ & 20 & 44.44 \\
& $24-28$ & 10 & 22.22 \\
& Total & $\mathbf{4 5}$ & $\mathbf{1 0 0}$ \\
& SHS1 & 15 & 33.33 \\
& SHS2 & 15 & 33.33 \\
& SHS3 & 15 & 33.33 \\
& Total & $\mathbf{4 5}$ & $\mathbf{1 0 0}$ \\
\hline \multicolumn{4}{c}{ Source: Field Survey (2018) }
\end{tabular}

Aside the student population, the study also focused on sampling the responses of both teachers and school management. Majority of the teachers and school management/staff are males (66.67\% for teachers; and $66.67 \%$ for management). It is also revealed that averagely most of the teachers and management staff are 30 years and above with a first degree educational qualification. More than $80 \%$ of the teachers and more than $65 \%$ of the management staff were also identified to have served their school for more than 5 years.

Table 5

\begin{tabular}{llcccc} 
Demographic Characteristics of Sampled Teachers and Management \\
\hline \multirow{4}{*}{ Gender } & Deachers & \multicolumn{3}{c}{ Management } \\
& Male & 30 & 66.67 & 20 & 66.67 \\
& Female & 15 & 33.33 & 10 & 33.33 \\
& Total & $\mathbf{4 5}$ & $\mathbf{1 0 0}$ & $\mathbf{3 0}$ & $\mathbf{1 0 0}$ \\
& $24-29$ & 5 & 11.11 & 0 & 0 \\
Age & $30-35$ & 15 & 33.33 & 5 & 16.67 \\
& $36-40$ & 10 & 22.22 & 10 & 33.33 \\
& $41-45$ & 15 & 33.33 & 15 & 50.0 \\
& Total & $\mathbf{4 5}$ & $\mathbf{1 0 0}$ & $\mathbf{3 0}$ & $\mathbf{1 0 0}$ \\
& Masters & 10 & 22.22 & 5 & 16.67 \\
\multirow{6}{*}{ Educational Level } & Professional & 0 & 0 & 5 & 16.67 \\
& First Degree & 30 & 66.67 & 10 & 33.33 \\
& HND & 5 & 11.11 & 10 & 33.33 \\
& Total & $\mathbf{4 5}$ & $\mathbf{1 0 0}$ & $\mathbf{3 0}$ & $\mathbf{1 0 0}$ \\
& 4yrs - 5yrs & 5 & 11,11 & 10 & 33.33 \\
& 5+ & 40 & 88.89 & 20 & 66.67 \\
& Total & $\mathbf{4 5}$ & $\mathbf{1 0 0}$ & $\mathbf{3 0}$ & $\mathbf{1 0 0}$ \\
\hline
\end{tabular}

Source: Field Survey (2018)

The main research question sought to assess the impacts of poor waste disposal management practices on Senior High Schools within the Wa Municipality of the Upper West Region of Ghana. The responses are presented below. 
One aspect of the questionnaire gathered data from respondents on whether they are comfortable with the waste disposal in schools within the Wa Municipality and this is presented in Table 6 .

Table 6

Respondents view on their comfort with the waste disposal in Senior High Schools within the Wa Municipality

\begin{tabular}{|c|c|c|c|c|}
\hline Item & Yes & No & $\mathbf{F}$ & $\%$ \\
\hline Are you comfortable living with the waste disposal in your school & $\begin{array}{l}10 \\
(8.33 \%)\end{array}$ & $\begin{array}{l}110 \\
(91.67 \%)\end{array}$ & 120 & $100 \%$ \\
\hline
\end{tabular}

Source: Field Survey (2018)

Results from Table 6 shows that majority of the respondents 110 out of 120 representing 91.67\% indicated that they are not comfortable living with waste disposal in their school whiles 10 out of the 120 respondents representing 8.33\% indicated that they are comfortable living with the waste disposal in their school. The implication of this result means that students, teachers and school management in Senior High Schools within the Wa Municipal are not comfortable living with waste disposal. This therefore means that sound waste management practice is essential, because students, teachers and school management as well as all other people can be aware and knowledgeable, but if they do not effectively practice sound waste management the desired outcome of effective waste management will be achieved with difficulty. This section aimed to evaluate the school students, teachers and school management current familiarity and involvement in waste management practices in their school.

The study also gathered data from respondents on whether poor waste disposal have negative effects on students, teachers and school management in Senior High Schools within the Wa Municipality and this is presented in Table 7.

Table 7

Negative Effects of Waste Disposal on Students, Teachers and School Management in Senior High Schools within the Wa Municipality

\begin{tabular}{|c|c|c|c|c|}
\hline Item & Yes & No & $\mathbf{F}$ & $\%$ \\
\hline $\begin{array}{l}\text { Do you have the belief that poor waste disposal have some } \\
\text { effects on students/teachers/school management? }\end{array}$ & $\begin{array}{l}120 \\
(100.0 \%)\end{array}$ & $\begin{array}{l}0 \\
(0.00 \%)\end{array}$ & 120 & $100 \%$ \\
\hline
\end{tabular}

Source: Field Survey (2018)

Results from Table 7 shows that all the respondents (students, teachers and school management) 120 representing $100 \%$ indicated that poor waste disposal have some negative effects on students/teachers/school management. The implication of this result means waste disposal in Senior High Schools within the Wa Municipality is coupled with so many negative effects. This is why Owusu (2015) postulated that the poor waste disposal situations in Senior High Schools in developing countries can have enormous implications on health, economic, finance, academic and the environment. The decomposing piles of wastes, especially in Senior High Schools in Ghana have the potential to attract and harbor vermin and rodents which spread diseases (Owusu, 2015). The accumulated wastes also attract foraging animals like dogs and goats which scatter infected waste materials, spreading diseases and causing a nuisance (Bello, 2007). The result from Table 7 is consistent with a 
study by Bello (2008) who asserted that waste materials that find their way into water courses like drains, streams and lagoons block the flow of flash waters during storms and cause extensive flooding in some of these cities.

In an interview with the Wa Municipal Director of Education, she remarked that,

"Poor waste disposal situation in the Senior High Schools in the Wa Municipality, constitutes a disaster for students, teachers and school management but nothing is been done about it."

One aspect of the questionnaire also gathered data from students, teachers and school management on problems encountered in poor waste disposal in Senior High Schools within the Wa Municipality and this is presented in Table 8.

Table 8

Problems Encountered in Poor Waste Disposal in Senior High Schools within the Wa Municipality

\begin{tabular}{cllll}
\hline \multicolumn{2}{l}{ Statements } & Students & Teachers & Management \\
\hline & & Mean & Mean & Mean \\
\hline a. & Disposal of waste is not strategically located & 2.782 & 2.714 & 3.929 \\
\hline b. & Waste materials are not properly disposed & 3.218 & 3.107 & 4.268 \\
\hline c. $\quad$ Delayed schedule of collection & 2.782 & 2.714 & 3.929 \\
\hline d. $\quad$ No designated sites for infectious waste & 2.985 & 2.857 & 3.929 \\
\hline e. & No safe disposal of infectious waste & 2.714 & 2.929 & 2.477 \\
\hline Overall Mean & $\mathbf{3 . 0 2 1}$ & $\mathbf{2 . 9 8 0}$ & $\mathbf{3 . 9 5 4}$ \\
\hline
\end{tabular}

Source: Field Survey (2018)

Table 8 shows the results of the problems encountered in poor waste disposal in Senior High Schools within the Wa Municipality. According both the students, teachers and school management in Senior High Schools within the Wa Municipality issues such as disposal of waste not strategically located, waste materials not properly disposed, delayed schedule of collection, no designated sites for infectious waste and no safe disposal of infectious waste are the problems encountered in poor waste disposal in Senior High Schools within the Wa Municipality. Based on the group assessments, it is clear that there are poor waste disposal management problems in Senior High Schools within the Wa Municipality of the Upper West Region of Ghana.

Moreover, it was also necessary to interrogate the experts in the field of waste management in Senior High Schools within the Wa Municipality to get their professional take on that and in line with these, some key informants were purposely selected from the district assembly under the waste management department, Environmental Protection Agency and Wa Municipal Education Directorate and below are some of the waste management problems they narrated.

The waste management expert in the Wa Municipal Assembly noted that,

"I have been here for the past four years and the major problem obstructing us starts from the generation stage, this is based on the fact that, we have done series of education on poor waste disposal but due to inadequate personnel and logistics waste disposal management is inadequate in Senior High Schools and I think until these problems are solved waste problems shall continue to be a challenge for Senior High Schools within the Wa Municipality." (Waste Management Expert, June, 2018)

The Wa Municipal Education Directorate when interviewed also remarked that; 
"The problem we have been facing managing waste disposal at Senior High Schools would have been easily tackled if all stakeholders responsible for waste disposal management come together. It is therefore, my concern that Senior High Schools authorities should corporate and partner with the Assembly, EPA and Zoomlion in waste disposal management if not a time will come all students, teachers and school management health may be in a danger." (Wa Municipal Education Directorate, June, 2018).

The result of this study is consistent with a study by Owusu (2014) who posited that maintaining a sound and healthy environment has always been a challenge in most Senior High Schools in developing countries. Furthermore, the research gathered data from respondents on how serious poor waste disposal is in Senior High Schools within the Wa Municipality and this is what Table 9 presents.

Table 9

Serious Nature of Poor Waste Disposal in Senior High Schools within the Wa Municipality

\begin{tabular}{|c|c|c|c|c|c|c|c|}
\hline & $\begin{array}{l}\text { Very serious } \\
\text { (Critical) }\end{array}$ & Serious & Neutral & Not too serious & Not serious at all & $\mathbf{F}$ & $\%$ \\
\hline Air pollution & $\begin{array}{l}120 \\
(100.0 \%)\end{array}$ & $\begin{array}{l}0 \\
(0.00 \%)\end{array}$ & $\begin{array}{l}0 \\
(0.00 \%)\end{array}$ & $\begin{array}{l}0 \\
(0.00 \%)\end{array}$ & $\begin{array}{l}0 \\
(0.00 \%)\end{array}$ & 120 & $100 \%$ \\
\hline Soil Pollution & $\begin{array}{l}0 \\
(0.00 \%)\end{array}$ & $\begin{array}{l}60 \\
(50.0 \%)\end{array}$ & $\begin{array}{l}0 \\
(0.00 \%)\end{array}$ & $\begin{array}{l}0 \\
(0.00 \%)\end{array}$ & $\begin{array}{l}60 \\
(50.0 \%)\end{array}$ & 120 & $100 \%$ \\
\hline Water pollution & $\begin{array}{l}0 \\
(0.00 \%)\end{array}$ & $\begin{array}{l}0 \\
(0.00 \%)\end{array}$ & $\begin{array}{l}0 \\
(0.00 \%)\end{array}$ & $\begin{array}{l}60 \\
(50.0 \%)\end{array}$ & $\begin{array}{l}60 \\
(50.0 \%)\end{array}$ & 120 & $100 \%$ \\
\hline
\end{tabular}

Source: Field Survey (2018)

Results from Table 9 shows that all the respondents 120 representing 100\% indicated that air pollution is very serious in Senior High Schools within the Wa Municipality. Again, 60 out of the 120 respondents representing 50\% indicated that soil pollution is serious in Senior High Schools within the Wa Municipality whiles 60 out of the 120 respondents representing 50\% also indicated that soil pollution is not serious at all in Senior High Schools within the Wa Municipality. Also, 60 out of the 120 respondents representing 50\% indicated that water pollution is not all that serious in Senior High Schools within the Wa Municipality whiles 60 out of the 120 respondents representing $50 \%$ also indicated that water pollution is not serious at all in Senior High Schools within the Wa Municipality.

The implication of this result means that poor waste disposal in Senior High Schools is causing a serious health problem on students, teachers and school management in the Wa Municipality since all the respondents 120 representing $100 \%$ expressed that air pollution is very serious or critical in Senior High Schools within the Wa Municipality. Furthermore, all the respondents expressed that high rate of population growth in Senior High Schools within the Wa Municipality have resulted in the generation of an enormous volume of solid waste, which poses a serious threat to environmental quality and human health. The respondents further expressed that the complex nature of disease outbreaks; cases of cholera as well as other diarrhea diseases in Senior High Schools is as a result of poor waste disposal.

The result in Table 9 is consistent with a study by Owusu (2014) who posited that improper solid waste management causes air, soil and water pollution. The problem of solid waste is very serious in third-world countries Senior High Schools (Owusu, 2014). 
Also, in an interview, the Wa Municipal Assembly Department of Waste Management Officer also remarked that,

"There are no records on waste management in senior high schools within the Wa Municipality. This therefore shows that waste disposal management in public Senior High Schools is an issue of concern by all."

Perhaps more telling is the response of the Wa Municipal Education directorate who was interviewed. She remarked that,

"There have been some waste management activities on some of the public Senior High Schools within the Wa Municipality in the past ten years but this is done by the politicians. This clearly suggests that waste disposal management in the past was done by unprofessional leading to the poor state of waste disposal management in Senior High School within the Wa Municipality. For example, when you are passing by Wa Senior High Technical School the odour is very serious causing air pollution."

The result of this study is consistent with a study by Seo (2006) who asserted that poor waste disposal management activities in Senior High Schools can bring about increase disease transmission or otherwise threaten students, teachers, school management and people working in the school health, contaminate grounds due to the poor waste disposal can bleed toxic materials and pathogenic organisms into an open refuse dump, and other ailments are also high causing mixing with leachate, and threatening the health and water supply of the surrounding school area and the unpleasant odour and unattractive appearance of piles of uncollected solid waste in schools can discourage people from schooling.

The study also gathered data from respondents on the ratings of the management of waste in Senior High Schools within the Wa Municipality and this is presented in Figure 1.

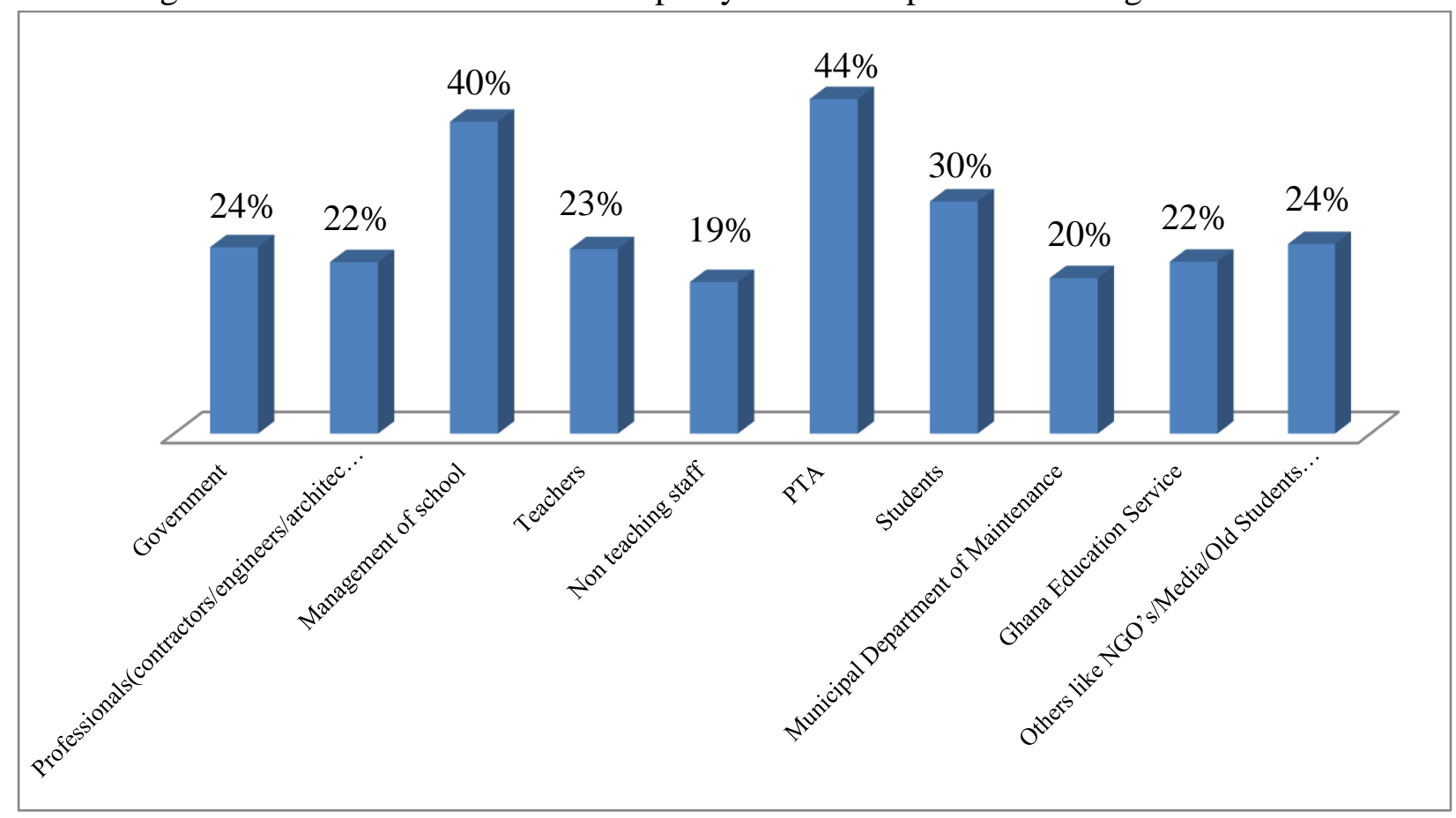

Figure 1: Task Performance Ratings of Management of the Waste Disposal by Stakeholders of Public Senior High Schools within the Wa Municipality

Source: Field Survey (2018) 
From figure 1 the performance ratings of all the stakeholders were below 0.6 which significance average or moderate performance. The implication is that none of the stakeholders were identified to perform their roles creditably. Nonetheless, the respondents revealed that the school management and PTA conducted their responsibilities relatively better compared to the other stakeholders. The respondents moreover indicated that the waste disposal management in Senior High Schools is not the responsibility of a specific institution or department but requires the collaborative efforts of several institutions and stakeholders who must perform their independent roles effectively. It was noted that the Government, Ministry of Education, Ghana Education Service, Municipal Assembly, School Management, Non-Governmental Organization and Students are all responsible for waste management in Senior High Schools within the Wa Municipality.

The policy development and major funding is made by the government through the Ministry of Education. The Ministry of Education is then expected to liaise with the Ghana Education Service in consultation with the Municipal Assembly and the school management to design the modalities for waste disposal management in Senior High Schools. When there are waste problems, the school management is first expected to report it to the Ministry of Education through the GES. However, minor and emergency waste disposal works can be initiated by the school management with the support of the PTA, the Old Students Associations and sometimes NGOs. The process can also commence from bottom up, although the top to bottom process is what is most common. The bottom-up process is usually used when waste management is required.

One aspect of the questionnaire gathered data from respondents on the impact of poor waste disposal on Senior High Schools within the Wa Municipality and the responses are presented below. All the respondents indicated that poor waste disposal can impact on school negatively. The respondents further expressed that waste was being dumped in open spaces in Senior High Schools within the Wa Municipality.

On the issue of the impact of poor waste disposal, all the respondents expressed that the effects of poor waste disposal and waste management on the well-being on Senior High Schools within the Wa Municipality are often expressed in health and environmental terms. Of equal importance, which requires the attention of stakeholders of the educational sector and other analysts of the school environment, are the social consequences of poor waste disposal. All the respondents further expressed that severe health and environmental consequences of poor waste disposal, and their direct and indirect links to the social consequences are:

1. Uncollected waste in Senior High Schools causes poor sanitation.

2. Social consequence of poor sanitation due to poor waste disposal management affects students. Thus, poor living environments have particularly far reaching consequences for students.

3. The respondents acknowledged that poor waste disposal is not good for the health of students and does not affords them opportunities for companionship, recreation and social learning.

4. Poor waste disposal causes diarrhea, skin diseases, typhoid fever and malaria among students in Senior High Schools within the Wa Municipality. 
5. Poor waste disposal situation affects the academic performance of students negatively.

\section{SUMMARY OF MAJOR FINDINGS}

A descriptive survey was employed for the study. A questionnaire and an interviews guide were used to gather data from three selected public Senior High School students, teachers and school management within the Wa Municipal. Respondents were selected through simple random and purposive sampling. The collected data was analyzed in simple percentages. The research question was to assess impacts of poor waste disposal management practices on Senior High Schools. The study found out that student's teachers and school management in Senior High Schools within the Wa Municipality are not comfortable living with the waste disposal in their schools.

Furthermore, it emerged from the study that there is poor waste disposal management problems in Senior High Schools within the Wa Municipality. The study further found out that poor waste disposal in Senior High Schools within the Wa Municipality have some negative effects on students/teachers/school management and this constitute disaster for students, teachers and school management. Moreover, the study found out that poor waste disposal in Senior High Schools within the Wa Municipality causes air pollution which is very serious to the health of students, teachers and school management in the Wa Municipality.

It also emerged from the study that high rate of population growth in Senior High Schools within the Wa Municipality have resulted in the generation of an enormous volume of solid waste, which poses a serious threat to environmental quality and human health and this causes disease outbreaks; cases of cholera as well as other diarrhea diseases in Senior High Schools within the Wa Municipality. Moreover, the study found out that waste disposal management in Senior High Schools is not the responsibility of a specific institution or department but requires the collaborative efforts of several institutions and stakeholders who must perform their independent roles effectively. It was noted that the Government, Ministry of Education, Ghana Education Service, Municipal Assembly, School Management, NonGovernmental Organization and Students are all responsible for waste management in Senior High Schools within the Wa Municipality.

It was realized that uncollected waste in Senior High Schools causes poor sanitation, social consequence of poor sanitation due to poor waste disposal management affects students, poor waste disposal are not good for the health of students and does not affords them opportunities for companionship, recreation and social learning, poor waste disposal causes diarrhea, skin diseases, typhoid fever and malaria among students in Senior High Schools within the Wa Municipality and lastly poor waste disposal situation affects the academic performance of students negatively.

\section{CONCLUSIONS}

Conclusions were drawn based on the research findings:

The study concludes that that there are poor waste disposal management problems in Senior High Schools within the Wa Municipality of the Upper West Region of Ghana. The study also concludes that, poor waste disposal in Senior High Schools within the Wa Municipality have some negative effects on students/teachers/school management and this constitute disaster for students, teachers and school management which causes air pollution in the 
schools which is very serious to the health of students, teachers and school management in the Wa Municipality ad this poses a serious threat to environmental quality and human health and this causes disease outbreaks; cases of cholera as well as other diarrhea diseases in Senior High Schools within the Wa Municipality.

\section{Recommendations}

Based on the findings of this study, the following recommendations could be raised:

First and foremost there should be provision of adequate dustbins in Senior High Schools within the Wa Municipality. Thus adequate dustbins should be provided by school management, Municipal Assembly and ZoomLion Ghana Ltd. Secondly, there should be regular collection of waste in Senior High Schools within the Wa Municipality by the institutions responsible.

Thirdly, the study also recommends proper management of waste disposal in Senior High Schools within the Wa Municipality. Thus the waste disposal sites in Senior High Schools within the Wa Municipality should be properly managed to avoid heaping of waste and burning. This will go a long way to prevent the burning of waste in Senior High Schools within the Wa Municipality.

Fourthly, the study further recommends to the Environmental Protection Agency in Wa Municipal which is the regulatory authority on sanitation to ensure routine monitoring of management of waste disposal sites in Senior High Schools within the Wa Municipality. The waste disposal sites in Senior High Schools within the Wa Municipality should also be relocated because of its negative environmental impact on the lives of students, teachers and school management.

\section{Acknowledgements}

The researcher wants to thank the editorial board of Fair East Publishers.

\section{Conflict of Interest Statement}

No conflict of interest has been declared by the author.

\section{Funding}

The researcher has not received any support for the publication of this paper.

\section{References}

Adewusi, A. O., \& Onifade, F. A. (2016). The effects of urban solid waste on physical environment and property transactions in Surulere local government area of Lagos State. Journal of Land use and Development Studies, 2(1), 71-90.

Agyei-Mensah, S., \& Owusu, G., (2009). Segregated by Neighborhoods? A portrait of ethnic diversity in the neighbourhoods of the Accra Metropolitan Area, Ghana. Population, Space and Place, DOI: 10.1002/psp.551.

Akpen, G.D., Tyagher, S.T., \& Ogori, P.O. (2005). Solid Waste Management in Urban Areas of Benue State, Nigeria. International Journal of Environmental Issues, 3(2), 54-59.

Ampofo, A. J. (2020). Constraints factors to maintenance of government Senior High School buildings in Wa Municipal. International Journal of Management \& Entrepreneurship Research, 2(3), 139-160. 
Ampofo, A. J., Amoah, S. T., \& Peprah, K. (2020). Examination of the current state of government buildings of Senior High Schools in Wa Municipal. International Journal of Management \& Entrepreneurship Research, 2(3), 161-193.

Ampofo, A. J., Nassè, T. B., Amoah, S. T., \& Peprah, K. (2020). Stakeholders responsibilities in public SHS buildings maintenance practices in the Wa Municipality. International Journal of Management \& Entrepreneurship Research, 2(3), 109-139.

Ampofo, A. J. (2019). Performance management and appraisal in improving teachers quality. Lambert Academic Publishing.

Ampofo, A. J., \& Acheampong, B. (2019). Carrier decisions of Kadjebi Asato Senior High School Students and their choice of academic programmes. Lambert Academic Publishing.

Bello, V. A. (2007). The effects of Ojota waste dump site on surrounding property values in Lagos Metropolis. Journal of Environmental Conservation and Research, 1(1\&2), 136-142.

Bello, M, O., \& Bello, V. A. (2008). Willingness to pay for better environmental services: Evidence from the Nigerian real estate market. Journal of African Real Estate Research, 1(1), 19-27.

Bello, V. A. (2009). The effects of waste dump sites on proximate property values in Lagos,Nigeria, (Unpublished Ph.D Dissertation), Federal University of Technology, Akure, Nigeria.

Boadi, K. (2004). Environment and Health in the Accra Metropolitan Area, Ghana. Academic Dissertation.

Boateng, C., \& Nkrumah, D. (2006). Managing Waste! The Attitudinal Change. Daily Graphic, $16^{\text {th }}$ December. Page 20.

Creswell, J.W. (2013). Research design; Qualitative and Quantitative approaches, Newbury Park, CA: Sage.

Gamble, H. B., Downing, R. H., Shortle, J. S., \& Epp, D. J. (2012). Effects of solid waste disposal sites on community development and residential property values. Final Report for The Bureau of Solid Waste Management Department of Environmental Resources, Commonwealth of Pennsylvania.

Gebril, A.O., Omran, A., Pakir, A.H.K., Aziz H.A. (2010). Municipal solid waste management in Benghazi (Libya): Current practices and challenges. Environmental Engineering and Management Journal, 9, 1289-1296.

Ghana Statistical Service, (May, 2012). Population \& Housing Census Summary. Report Of Final Results.

Gyebi E. (2010). The Chronicle Ghana: Tamale Assembly makes breakthrough in waste management. 19th March 2010 Edition of the Chronicle.

ISSER/CHF Ghana, (2017). Situational analysis of selected slum communities in Accra and Sekondi-Takoradi: final report. Accra: CHF Ghana.

Kumah, A.M. (2007). The Situation of Solid Waste in Ghana. Accra, Ghana

Martin, O. A. (2011). Governance Crisis or Attitudinal Challenges? Generation, Collection, Storage and Transportation of Solid Waste in Ghana. Integrated Waste Management. In Tech 1, (978- 953-307-469-6) 
Mensah, A., \& Larbi, E. (2005). Fact Sheet Solid Waste Disposal (SWD) in Ghana. www.trend.watsan.net. Accessed on 10th January, 2018.

Miller, C. (2004). Wastage. Food Waste. Available from http:// wastage.com/mag/wastefood-waste-2/ Accessed in January 10, 2018.

Misra, V., \& Pandey, S.D. (2005). Hazardous waste, impact on health and environment for development of better waste management strategies in future in India. Environmental International, 31(3), 417-431.

Owusu, G., Agyei-Mensah, S., \& Lund, R. (2015). Slums of hope and slums of despair' mobility and livelihoods in Nima, Accra. Norsk Geografisk Tidsskrift - Norwegian Journal of Geography, 62, 180-190.

Owusu, G., \& Oteng-Ababio, M. (2014). Moving Unruly Contemporary Urbanism Towards Sustainable Urban Development in Ghana by 2030. American Behavioral Scientist, DOI 10.1177/00027642/4550302.

Owusu-Sekyere E. (2015). Epidemiological Analysis of Households near Three Solid WasteDumpsites in Kumasi (Unpublished Thesis), University of Ghana, Accra.

PAR. (2011). Performance audit report of the auditor-general on solid waste management by Accra Metropolitan Assembly (AMA) Ref. No. AG.01/109/Vol.2/34.

Parker, B.J. (2003). Solid waste landfills and residential property values, White Paper, National Solid Wastes Management Association, Washington, DC.

Post, J., \& Obirih-Opareh, N. (2012). Quality assessment of public and private modes of solid waste collection in Accra, Ghana. Habitat Int'1 26:95-112.

Seo, S. (2006). Environmental Impact of Solid Waste Treatment Methods in Korea. Journal of Engineering, 130(1), 81-89.

Simon, D. (2014). New evidence and thinking on urban environmental change challenges IDPR, 36(2). Doi: 10.3828/idpr.2014.9. Solid Wastes Management Association, Washington, DC.

Tsiboe, (2004). An Analysis of Solid Waste Management in Accra, Ghana (Master's Thesis), Roskilde University, pp. 13-14.

UNFPA, (2016). UNFPA, State of the world population, 2009: facing a changing world women, population and climate. New York: UNFPA.

UN-Habitat. (2008). State of African Cities (2008): A framework for addressing urban challenge in Africa. Nairobi.

UN-Habitat (2012). Solid Waste Management in the World's Cities: Water and Sanitation in the World's Cities 2010. In: Earthscan (Series Ed.).

Wilson, D.C. (2007). Development drivers for waste management. Waste Management \& Research, 25(3), 198-207.

Yurttas, G.D., Sülüna, Y. (2010). What are the most important environmental problems according to the second grade primary school students. Procedial Social and Behavioral Sciences, 2, 1605 -1609.

Zahari, R. K. (2017). Urban Environmental Hazards: A Case Study of Flood Hazards in Kuala Lumpur, Malaysia (Unpublished Ph.D Thesis) The University of Nottingham. 